\title{
Laporan Literatur Review
}

\author{
Oleh \\ (M. Ian Erwin Najamudin) \\ Program Studi Pendidikan Sejarah FKIP ULM
}

NIM

(1810111110011)

\section{Karya ilmiah yang di review}

Anis, M. Z. A., Putro, H. P. N., Susanto, H., \& Hastuti, K. P. (2020). Historical Thinking Model in Achieving Cognitive Dimension of Indonesian History Learning. PalArch's Journal of Archaeology of Egypt/Egyptology, 17(7), 7894-7906.

\section{Ringkasan isi artikel}

Berdasarkan konstruktivisme pendidik sejarah setuju jika peserta didik dan guru dibekali dengan pengetahuan tentang metode sejarah yang dikenal sebagai pemikiran sejarah. Pemikiran sejarah yang dimaksudkan dari ahli luar dan dalam negeri terkait dengan keterkaitan dua pandangan yang berlawanan yaitu keterampilan intelektual dan keterampilan perilaku. Proses pembelajaran sejarah di SMA, guru masih mengajar secara konvensional dan belum mengembangkan keterampilan intelektual. Kecenderungan guru sejarah dalam mengajar yang lebih menekankan hafalan yang berkaitan dengan banyaknya nama tokoh, tanggal dan tahun suatu peristiwa monumental yang mungkin tidak berarti bagi peserta didik. Peserta didik juga sering mudah lupa tanggal, tahun bahkan nama tokoh sejarah yang dipelajari. Research of Seixas, berupaya mengaplikasikan pemikiran sejarah secara besar-besaran di Amerika Utara. Artikel tersebut berisi investigasi naratif tentang reformasi pendidikan sejarah melalui asesmen berbasis kelas pembangunan .

Kajian mengenai pengembangan model berpikir sejarah dengan berbagai model evaluasi yang digunakan berkembang mulai dari ketidakpuasan terhadap konsep dan penilaian pembelajaran konservatif hingga solusi tentang pemikiran sejarah, termasuk penilaian dan evaluasinya. kemajuan pendidikan karena memberikan kemungkinan besar dalam proses pembelajaran menjadi demokratis dan kritis serta menjadikan pendidikan lebih terbuka. Pemikiran historis sebagai tujuan pembelajaran memerlukan penilaian yang mampu menerjemahkan tujuan dan indikator pencapaian kompetensi dalam bentuk instrumen evaluasi yang valid dan reliabel sehingga mampu memberikan penilaian terhadap hasil belajar yang ditentukan. Penelitian dilaksanakan tiga tahap yaitu tahap analisis kebutuhan, penyusunan instrumen penilaian berfikir historis, dan terakhir pengujian instrumen penilaian.

Studi yang sudah ada menunjukkan bahwa minat peserta didik yang semakin meningkat dalam belajar sejarah harus dimotivasi dengan menyelidiki masalah yang 
mereka hadapi melalui pemikiran sejarah yang ditafsirkan dengan berbagai perspektif. Di sisi lain, pemikiran sejarah menekankan pada sikap kritis terhadap fakta, mensintesis, menafsirkan, merefleksikan, dan menghubungkan peristiwa terkini dengan masa lalu . Pemikiran HAT ternyata lebih baik dari pada mereka yang di tes menggunakan soal pilihan ganda. Setidaknya ada tiga topik pembahasan yang dapat ditemukan dari penelitian sebelumnya, yaitu memenuhi kebutuhan untuk mengembangkan model pemikiran sejarah, mencari model evaluasi pemikirannya.

\section{Relevansi jenis/metode evaluasi yang dibahas}

Dari hasil analisis kebutuhan berdasarkan kompetensi kurikulum program studi, diketahui jika dimensi dengan cakupan terluas adalah dimensi faktual dan konseptual, dengan aspek kognitif terendah pada level C3 dan level C6 tertinggi. Maka, kebutuhan akan instrumen penilaian sebagian besar harus mencakup dimensi faktual dan konseptual. Dengan demikian terdapat 4 dimensi kognitif yang merepresentasikan seluruh kompetensi dalam kurikulum program studi. Dimensi kognitif kemudian diterjemahkan ke dalam model instrumen sesuai dengan kategori masing-masing dimensi kognitif.

Penilaian dalam APUSH terdiri tes pilihan ganda, dan pertanyaan respon bebas. Pilihan ganda digunakan untuk mengukur pencapaian aspek faktual sedangkan FRQ digunakan untuk mengukur kemampuan membangun argumen dan penalaran evaluatif. Selain penelitian di atas, juga dilakukan penelitian terhadap hasil validasi History Assessment of Thinking Skill yang digunakan untuk menguji kemampuan berpikir HAT dengan menggunakan teknik tes essay, ternyata hasilnya lebih baik dari pada yang diuji menggunakan pertanyaan pilihan ganda. Perencanaan penilaian pemikiran historis didasarkan pada hasil analisis kebutuhan. Berdasarkan analisis kebutuhan, instrumen yang disusun meliputi 4 dimensi kognitif; faktual, konseptual, prosedural, dan metakognitif.

Dari hasil uji validitas dapat diketahui hasil validasi untuk 4 model instrumen yang dikembangkan dalam penelitian ini. Hasil uji menunjukkan hanya ada satu instrumen yang tidak valid yaitu item 17 model soal pilihan ganda. Data dari item yang tidak valid tidak digunakan dalam analisis hasil penelitian, dan karena representasi masing-masing indikator telah terpenuhi maka tidak mempengaruhi proses analisis data.

Berdasarkan hasil uji Anti-Image Matries dapat diketahui bahwa nilai MSA pada masing-masing variabel lebih dari 0,50, sehingga keempat variabel tersebut dapat digunakan dalam analisis faktor. Hasil analisis faktor menunjukkan bahwa pengetahuan inilah yang menjadi kunci pencapaian dimensi kognitif.Penelitian tentang pengembangan model berpikir sejarah dengan berbagai model evaluasi yang digunakan telah berkembang mulai dari ketidakpuasan terhadap konsep dan 
penilaian pembelajaran konservatif hingga solusi tentang pemikiran sejarah. termasuk penilaian dan evaluasinya.

\section{Simpulan}

Instrumen berpikir sejarah yang dianggap penting ternyata masih belum terukur sehingga pendidik berupaya untuk meneliti instrumen yang diperlukan untuk pembelajaran sejarah. Instrumen yang dikembangkan dalam penelitian adalah instrumen penilaian berpikir historis yang mengacu pada pencapaian kognitif meliputi faktual, konseptual, prosedural dan metakognitif. Untuk mendapatkan kesesuaian instrumen yang dirancang, pengembangan instrumen ini diawali dengan analisis kebutuhan yang dilanjutkan dengan studi tentang jenis instrumen standar yang telah digunakan dalam kajian lapangan sejarah.

\section{Referensi}

Anis, M. Z. A., Putro, H. P. N., Susanto, H., \& Hastuti, K. P. (2020). Historical Thinking Model in Achieving Cognitive Dimension of Indonesian History Learning. PalArch's Journal of Archaeology of Egypt/Egyptology, 17(7), 78947906. 